\title{
PENGARUH MODEL PEMBELAJARAN KOOPERATIF THE POWER OF TWO TERHADAP KEMAMPUAN KOMUNIKASI MATEMATISSISWA SMP
}

\section{(THE EFFECT OF COOPERATIVE LEARNING MODELS THE POWER OF TWO TO MATHEMATICS COMMUNICATION ABILITY IN THE MIDDLE SCHOOL)}

\author{
Hadi Sutiawan ${ }^{1}$, Anggi Rahmani ${ }^{2}$ \\ ${ }^{1}$ STKIP Setia Budhi Rangkasbitung, hadi.sutiawan@stkipsetiabudhi.ac.id \\ ${ }^{2}$ STKIP Setia Budhi Rangkasbitung, anggi.rahmani@stkipsetiabudhi.ac.id
}

\begin{abstract}
Abstrak
Penelitian ini bertujuan untuk mengetahui pengaruh model pembelajaran kooperatif tipe the power of two terhadap kemampuan komunikasi matematis siswa SMP. Penelitian ini dilakukan di SMP Pariskian. Metode yang digunakan dalam penelitian ini adalah quasi eksperimen. Teknik sampel yang digunakan yaitu cluster random sampling. Teknik pengumpulan data yaitu tes kemampuan komunikasi matematis. Hasil penelitian menunjukkan bahwa (1) Pencapaian akhir kemampuan komunikasi matematis siswa yang mendapatkan model pembelajaranthe power of two lebih tinggi daripada siswa yang mendapatkan model pembelajaran ekspositori; (2) Peningkatan kemampuan komunikasi matematis siswa yang mendapatkan model pembelajaranthe power of two, lebih tinggi siswa yang mendapatkan daripada siswa yang mendapatkan model pembelajaran ekspositori.
\end{abstract}

Kata kunci: The Power of Two, Komunikasi Matematis

\begin{abstract}
This study aims to determine the effect of the power of two cooperative learning model on the mathematical communication skills of junior high school students. This research was conducted at Pariskian Middle School. The method used in this research is quasi-experimental. The sample technique used is cluster random sampling. Data collection techniques are tests of mathematical communication skills. The results showed that (1) The final achievement of mathematical communication skills of students who got the power of two learning model was higher than students who got expository learning models; (2) Increased mathematical communication skills of students who get the power of two learning model, higher students get than students who get expository learning models.
\end{abstract}

Keywords: The Power of Two, Mathematical Communication 


\section{PENDAHULUAN}

Matematika sejak dini diperlukan untuk menguasai dan mencipta teknologi di masa depan. Setiap kegiatan manusia sangat erat kaitannya dengan matematika. Berbagai informasi dan gagasan banyak dikomunikasikan atau disampaikan dengan bahasa matematika, serta banyak masalah yang dapat disajikan ke dalam model matematika. Maka dari itu matematika diberikan kepada siswa agar memiliki kemampuan berpikir logis, analitis, sistematis, kritis, dan kreatif, serta memiliki kemampuan bekerjasama.

Pemahaman bahasa matematika tidak mudah untuk dikuasai oleh siswa.Menurut Asquith et al. (2007) siswa mengalami kesulitan besar dalam menerjemahkan bahasa verbal ke bentuk representasi simbol. Sedangkan Knuth et al. (2005), siswa kelas 6, 7, dan 8 mengalami kesulitan dalam melakukan interpretasi simbol literal dan menggunakan konsep variabel. Penyebab siswa kesulitan belajar matematika terkait lemahnya kemampuan membaca secara umum, dan ketidakmampuan membaca secara khusus, apalagi matematika merupakan ilmu yang bahasanya sarat oleh simbol dan istilah. Kemampuan dan keterampilan terkait dengan pemahaman bahasa matematika sudah dirumuskan dalam tujuan mata pelajaran matematika. Salah satu tujuan mata pelajaran matematika (BSNP, 2006) yakni mengomunikasikan gagasan dengan simbol, tabel, diagram, atau media lain untuk memperjelas keadaan atau masalah. Berdasarkan tujuan mata pelajaran matematika di atas tampak arah orientasi pembelajaran matematika terkait dengan kemampuan komunikasi matematis.

Baroody (1993) mengungkapkan bahwa paling tidak ada dua alasan penting yang menjadikan komunikasi dalam matematika perlu menjadi fokus perhatian. Pertama, mathematics as language: matematika tidak hanya sekedar alat bantu berpikir, alat untuk mengemukakan pola-pola atau menyelesaikan masalah, namun matematika juga merupakan alat yang tidak terhingga nilainya untuk mengomunikasikan berbagai ide dengan jelas, tepat, dan cermat. Kedua, mathematics learning as social activity: matematika sebagai aktivitas sosial dalam pembelajaran matematika, interaksi antara siswa seperti juga komunikasi antara guru dan siswa yang merupakan bagian penting untuk memelihara dan mengembangkan potensi matematika siswa.

Pentingnya kemampuan komunikasi matematis dalam kompetensi yang harus dimiliki tidak sejalan dengan hasil yang diharapkan.Hasil penelitian Kadir (2010) juga melaporkan bahwa rerata skor kemampuan komunikasi matematis yang diperoleh siswa hanya mencapai 3,9, sementara skor maksimal idealnya 10, dan secara umum menyimpulkan bahwa kemampuan komunikasi matematis siswa masih rendah. Penelitian lain yang dilakukan Pujiastuti (2014) menyimpulkan bahwa kemampuan komunikasi matematis siswa SMP masih rendah. Kesimpulan ini didasarkan pada rerata skor kemampuan komunikasi matematis yang diperoleh siswa hanya mencapai 8,5 dan skor tertinggi yang diperoleh siswa hanya mencapai 14, sementara skor maksimal idealnya 30. Ditinjau dari persentasenya, rerata skor kemampuan komunikasi matematis siswa hanya mencapai $28,33 \%$ dari skor maksimal ideal.Kemampuan siswa dalam mengomunikasikan ide-ide matematika kurang disebabkan beberapa faktor antara lain: (1) model pembelajaran yang terpaku padapembelajaran yang bersifat statis dan monoton, (2) pembelajaran yang dilaksanakan guru kurang memberikan kesempatan pada siswa untuk saling berkomunikasi, (3) pada umunya motivasi siswa untuk belajar 
matematika rendah, (4) masih banyak siswa yang berpendapat bahwa matematika itu sulit dan membosankan.

Kemampuan komunikasi matematis dalam pembelajaran matematika merupakan salah satu kompetensi dasar yang harus dimiliki siswa dalam pembelajaran matematika di sekolah.National Council of Teachers of Mathematics atau NCTM (2000), menyatakan bahwa standar matematika sekolah haruslah meliputi standar isi dan standar proses. Standar proses meliputi: (1) penyelesaian masalah (problem solving);(2) penalaran dan pembuktian (reasoning and proof);(3) komunikasi (communication); (4) koneksi (connection); dan representasi (representation).

Dengan diberlakukannya kurikulum 2013 revisi di sekolah-sekolah menuntut siswa untuk bersikap aktif, kreatif dan inovatif dalam mengikuti setiap proses pembelajaran. Salah satu upaya untuk membangun kemampuan pemahaman konsep matematika dan menurunkan kecemasan matematika siswa adalah melalui penerapan pembelajaran yang tepat, yang salah satunya yaitu dengan menerapkan model pembelajaran kooperatif tipe the power of two. Zaini, dkk (2008: 52) menyatakan bahwa the power of two adalah aktivitas pembelajaran yang digunakan untuk mendorong pembelajaran kooperatif dan memperkuat arti penting serta manfaat sinergi dua orang. Hal ini dikarenakan proses belajar dengan menerapkan model pembelajaran kooperatif lebih berpusat pada siswa, karena meskipun tetap dalam bimbingan guru, siswa mempelajari sendiri bersama anggota kelompoknya mengenai materi yang diberikan. Dengan menerapkan model pembelajaran kooperatif tipe the power of two, maka diskusi dalam kelompok akan lebih maksimal, karena dua siswa dalam satu kelompok tidak akan ada yang merasa terabaikan.

\section{KAJIAN TEORI}

\section{Model Pembelajaran Kooperatif Tipe The Power of Two}

Jenis pembelajaran kooperatif yang digunakan dalam penelitian ini adalah the power of two.Silberman (2009) menyatakan bahwa pembelajaran kooperatif tipe the power of two berarti menggabungkan kekuatan dua kepala dengan membentuk kelompok kecil, yaitu masing-masing siswa berpasangan. Model pembelajaran ini mempunyai prinsip bahwa berpikir berdua lebih baik daripada sendiri. Suprijono (2013) mengungkapkan bahwa model the power of two diawali dengan mengajukan pertanyaan. Diharapkan pertanyaan yang dikembangkan adalah pertanyaan yang membutuhkan pemikiran kritis.

Zaini, dkk (2008: 52) menyatakan bahwa the power of two adalah aktivitas pembelajaran yang digunakan untuk mendorong pembelajaran kooperatif dan memperkuat arti penting serta manfaat sinergi dua orang. Hal ini dikarenakan proses belajar dengan menerapkan model pembelajaran kooperatif lebih berpusat pada siswa, karena meskipun tetap dalam bimbingan guru, siswa mempelajari sendiri bersama anggota kelompoknya mengenai materi yang diberikan. Dengan menerapkan model pembelajaran kooperatif tipe the power of two, maka diskusi dalam kelompok akan lebih maksimal, karena dua siswa dalam satu kelompok tidak akan ada yang merasa terabaikan.Langkah-langkah model pembelajaran the power of two menurut Silberman (2009: 161) adalah sebagai berikut: (1) Berilah siswa satu atau lebih pertanyaan yang membutuhkan refleksi dan pikiran; (2) Mintalah siswa untuk menjawab pertanyaan sendiri-sendiri; (3) Setelah semua 
melengkapi jawabannya, bentuklah ke dalam pasangan dan mintalah mereka untuk berbagi jawaban dengan yang lain; (4) Mintalah pasangan tersebut membuat jawaban baru untuk masing-masing pertanyaan dengan memperbaiki respons masing-masing individu; (5) Ketika semua pasangan selesai menulis jawaban baru, bandingkan jawaban dari masing-masing pasangan ke pasangan yang lain.

Penerapan the power of two dalam pembelajaran lebih menekankan pada aktivitas yang dilakukan secara berpasangan dan lebih mengutamakan kerjasama.Kerjasama yang diwujudkan dalam bentuk diskusi menitikberatkan pada aktivitas bertanya, menjawab, bertukar pikiran tentunya membutuhkan pemahaman ketika masing-masing individu harus mengemukakan pendapat atau idenya dalam mencapai suatu kesimpulan.Apalagi, kemampuan pemahaman dibutuhkan untuk mampu mengaitkan suatu konsep dengan konsep lainnya.

Sanaki (2006) mengungkapkan bahwa penerapan strategi belajar kekuatan berdua (the power of two) denganlangkah-langkah atau prosedur yang dilakukan guru, adalah sebagai berikut:

a. Membuat problem, dalam proses belajar guru memberikan satu atau lebih pertanyaan kepada siswa yang membutuhkan refleksi.

b. Guru meminta siswa untuk merenung dan menjawab pertanyaan sendirisendiri.

c. Guru membagi siswa berpasang-pasangan. Dalam proses belajar setelah semua siswa melengkapi jawabannya, bentuklah ke dalam pasangan dan mintalah mereka untuk berbagai (sharing) jawaban dengan yang lain.

d. Guru meminta pasangan untuk berdiskusi mencari jawaban baru. Dalam proses belajar, guru meminta siswa untuk membuat jawaban baru untuk masingmasing pertanyaan dengan memperbaiki respon masing-masing individu.

e. Guru meminta peserta untuk mendiskusikan hasil sharingnya. Dalam proses belajar, ketika semua pasangan selesai menulis jawaban baru, bandingkan jawaban dari masing-masing pasangan ke pasangan yang lain.

Zaini, dkk (2008) mengemukakan bahwa langkah-langkah dalam pelaksanaan model the power of two adalah sebagai berikut:

a. Ajukan satu atau lebih pertanyaan yang menuntut perenungan dan pemikiran.

b. Siswa diminta untuk menjawab pertanyaan-pertanyaan tersebut secara individual.

c. Setelah semua siswa menjawab dengan lengkap semua pertanyaan, mintalah mereka untuk berpasangan dan saling bertukar jawaban satu sama lain dan membahasnya.

d. Mintalah pasangan-pasangan tersebut membuat jawaban baru untuk setiap pertanyaan, sekaligus memperbaiki jawaban individual mereka.

e. Ketika semua pasangan telah menulis jawaban-jawaban baru bandingkan jawaban setiap pasangan di dalam kelas.

Langkah-langkah model pembelajaran the power of two menurut

Silberman (2009) adalah sebagai berikut:

a. Berilah siswa satu atau lebih pertanyaan yang membutuhkan refleksi dan pikiran.

b. Mintalah siswa untuk menjawab pertanyaan sendiri-sendiri.

c. Setelah semua melengkapi jawabannya, bentuklah ke dalam pasangan dan mintalah mereka untuk berbagi jawaban dengan yang lain. 
d. Mintalah pasangan tersebut membuat jawaban baru untuk masing-masing pertanyaan dengan memperbaiki respons masing-masing individu.

e. Ketika semua pasangan selesai menulis jawaban baru, bandingkan jawaban dari masing-masing pasangan ke pasangan yang lain.

Berdasarkan uraian diatas, maka model pembelajaran the power of two yang digunakan dalam penelitian yaitu menurut Siberman.

\section{Kemampuan Komunikasi Matematis}

Matematika merupakan bahasa universal dimana untuk simbol yang terdapat dalam matematika dapat dipahami oleh semua orang. Sehingga kemampuan komunikasi matematis sangat perlu dipelajari oleh siswa. Hal tersebut diperkuat oleh pendapat yang diungkapkan oleh Lindquist berdasarkan pada National Council of Teachers of Mathematics (NCTM, 2000) mengungkapkan bahwa:kemampuan komunikasi dalam matematika perlu dibangun agar siswa dapat: (1) merefleksi dan mengklarifikasi dalam berpikir mengenai gagasan-gagasanmatematika dalam berbagai situasi, (2) memodelkan situasi dengan lisan,tertulis, gambar grafik dan secara aljabar, (3) mengembangkan pemahaman terhadap gagasan matematis termasuk peranan definisi dalam berbagai situasimatematika, (4) menggunakan keterampilan membaca, mendengar dan menulismenginterpretasikan dan mengevaluasi gagasan matematis, (5) mengkaji gagasan matematis melalui konjektur dan alasan yang meyakinkan, (6) memahami nilaidari notasi dan peran matematika dalam pengembangan gagasan matematis.

Bahasa matematika menggunakan empat kategori symbol (Zainab, 2011:2): simbol-simbol untuk gagasan (bilangan dan elemen-elemen), simbolsimbol untuk relasi (yang mengindikasikan bagaimana gagasan-gagasan dihubungkan atau berkaitan satu sama lain), simbol-simbol untuk operasi (yang mengindikasikan apa yang dilakukan dengan gagasan-gagasan), dan simbolsimbol untuk nada baca (yang mengindikasikan urutan dimana matematika itu diselesaikan).

Dalam Depdiknas (Anisah, 2013:1) komunikasi matematis merupakan aspek yang sangat penting dalam belajar matematika, karena melalui komunikasi matematis, siswa memiliki kemampuan secara logis dan kritis serta mengembangkan aktivitas kreatif dalam memecahkan masalah dan mengomunikasikan ide-ide matematika. Ini juga sejalan dengan apa yang dikemukakan Karlimah (Safrilda, 2012:21) menuliskan hasil penyelesaian masalah matematika, mendorong siswa untuk merefleksikan pekerjaan mereka dan mengklarifikasi ide-ide untuk mereka. Ketika siswa dilibatkan secara komunikatif dalam mengerjakan masalah matematis, berarti mereka diminta untuk memikirkan ide ide mereka, atau berbicara dan mendengarkan siswa lain, dalam berbagi ide, strategi dan solusi. Oleh karena itu keterampilan komunikasi matematis perlu pula dimiliki oleh siswa. Yaniawati (2010:116) juga menambahkan bahwa komunikasi dalam matematika dapat mempermudah guru untuk memahami kemampuan siswa dalam menginterpretasi dan mengekspresikan pemahamannya tentang konsep dan proses matematika yang mereka pelajari.

Melihat pentingnya komunikasi matematis bagi siswa, NCTM (2000:60) menuliskan standar komunikasi program pengajaran dari Pra-TK sampai kelas 12 harus memungkinkan semua siswa untuk: (1) mengatur dan menggabungkan 
pemikiran matematis mereka melalui komunikasi, (2) mengkomunikasikan pemikiran matematika secara koheren dan jelas kepada teman, guru dan orang lain, (3) menganalisa dan menilai pemikiran dan strategi matematis orang lain, (4) menggunakan bahasa matematika untuk menyatakan ide matematika dengan tepat. Menurut Sumarmo (2010:6) kegiatan yang tergolong pada komunikasi matematis di antaranya adalah: (1) menyatakan suatu situasi, gambar, diagram, atau benda nyata ke dalam bahasa, simbol, idea, atau model matematik; (2) menjelaskan idea, situasi, dan relasi matematika secara lisan atau tulisan; (3) mendengarkan, berdiskusi, dan menulis tentang matematika; (4) membaca dengan pemahaman suatu representasi matematika tertulis; (5) mengungkapkan kembali suatu uraian atau paragraf matematika dalam bahasa sendiri.

Selain pengertian matematika sebagai alat komunikasi, ada juga pengertian komunikasi dalam matematika yakni berkaitan dengan kemampuan keterampilan siswa dalam berkomunikasi. Standar evaluasi untuk mengukur kemampuan komunikasi (NCTM, 1989:214) adalah: (1) kemampuan mengekspresikan ide-ide matematis melalui lisan, tulisan, dan mendemonstrasikannya serta menggambarkannya secara visual; (2) kemampuan memahami, mengiterpretasikan, dan mengevaluasi ide-ide matematis baik secara lisan, tulisan, maupun dalam bentuk visual lainnya; (3) kemampuan dalam menggunakan istilah-istilah, notasi-notasi matematika dan struktur-strukturnya untuk menyajikan ide-ide, menggambarkan hubungan-hubungan dengan model-model situasi.

Indikator kemampuan komunikasi matematis menurut Sumarmo (2006:3), yaitu (a) menghubungkan benda nyata, gambar, dan diagram ke dalam ide matematika, (b) menjelaskan ide, situasi, dan relasi matematika, secara lisan atau tulisan, dengan benda nyata, gambar, grafik, dan aljabar, (c) menyatakan peristiwa sehari-hari dalam bahasa atau simbol matematika, (d) mendengarkan, berdiskusi, dan menulis tentang matematika, (e) membaca dengan pemahaman suatu presentasi matematika tertulis, (f) membuat konjektur, menyusun argumen, merumuskan definisi, dan generalisasi, (g) menjelaskan dan membuat pertanyaan tentang matematika yang telah dipelajari.

Adapun indikator yang menunjukkan kemampuan komunikasi matematis dalam penelitian ini yang diambil dari Sumarmo (2006:3) yaitu:

a. Menghubungkan benda nyata, gambar, dan diagram ke dalam ide matematika

b. Menjelaskan ide, situasi, dan relasi matematik, secara tulisan, dengan benda nyata, gambar, grafik, dan aljabar

c. Menyatakan peristiwa sehari-hari dalam bahasa atau simbol matematika

d. Membuat konjektur, menyusun argumen, merumuskan definisi dan generalisasi.

\section{METODE}

Penelitian ini merupakan penelitian kuasi eksperimen dengan variabel bebas, yaitu model pembelajarankooperatif tipe the power of two, dan variabel terikat yaitu kemampuan komunikasi matematissiswa pada pokok bahasan bangun datar. Populasi pada penelitian ini adalah seluruh siswa SMP Swasta Kota Serang tahun pelajaran 2018/2019. Populasi target pada penelitian ini yaitu seluruh siswa SMP Pariskian dan populasi terjangkaunya seluruh siswa kelas VIII SMP 
Pariskian. Pengambilan sampel dilakukan dengan teknik cluster random sampling.

Pengambilan sampel dapat diuraikan sebagai berikut: (1) menentukan SMP Swasta Sekota Serang dengan Akreditasi A sebagai populasi penelitian; (2) memilih secara random sampling SMP Swasta Sekota Serang dengan akreditasi A, sehingga terpilih yaitu SMP Pariskian sebagai populasi target;(3) mengidentifikasi seluruh siswa SMP Pariskian dan menentukan populasi terjangkau yaitu seluruh siswa kelas VIII SMP Pariskian tahun ajaran 2018/2019. Selanjutnya melakukan uji prasyarat yaitu uji normalitas dan uji homogenitas, kemudian uji kesamaan rata-rata untuk menguji kesetaraan sampel penelitian dengan menggunakan nilai UAS matematika semester ganjil. Siswa kelas VIII SMP Pariskian dari 5 rombongan belajar.Instrumen yang digunakan untuk mengukur kemampuan komunikasi matematis siswa yaitu Tipe tes uraian.Untuk menguji validitas tiap butir soal, digunakan jenis statistika Koefisien Korelasi Product Moment dengan angka kasardari Karl Pearson kemudian dilanjutkan uji reliabilitas dengan menggunakan rumus Cronbach Alpha. Teknik analisis data terdiri dari teknik analisis deskriptif, pengujian prasayarat analisis (normalitas dan homogenitas), dan pengujian hipotesis.

\section{HASIL DAN PEMBAHASAN}

Data mengenai kemampuan komunikasi matematis diperoleh dari hasil pretes dan postes pada masing-masing kelas yang disajikan dalam tabel dibawah ini.

Tabel 1. Statistik Deskriptif Data Pretes, Postes, dan Gain

\begin{tabular}{c|cccccc}
\hline \multirow{2}{*}{ Kelas } & \multicolumn{3}{|c}{ Eksperimen } & \multicolumn{3}{c}{ Kontrol } \\
\cline { 2 - 7 } & Pretes & Postes & Gain & Pretes & Postes & Gain \\
\hline Skor Ideal & 40 & 40 & 1 & 40 & 40 & 1 \\
\hline Rata-rata & 16,25 & 27,38 & 0,47 & 14,08 & 21,68 & 0,34 \\
\hline Varians & 25,23 & 26,30 & 0,032 & 22,99 & 49,89 & 0,033 \\
\hline Standar Deviasi & 5,02 & 5,13 & 0,18 & 4,79 & 7,06 & 0,18 \\
\hline Skor Tertinggi & 28 & 37 & 0,79 & 25 & 36 & 0,85 \\
\hline Skor Terendah & 8 & 18 & 0,10 & 6 & 10 & 0,04 \\
\hline
\end{tabular}

Dari Tabel 1 diatas, hasil analisis data pretes kelas eksperimen dari 32 siswa diperoleh skor tertinggi 28 dan skor terendah 8. Pada kelas kontrol dengan siswa sebanyak 31 siswa diperoleh skor tertinggi 25 dan skor terendah 6 . Sementara itu, hasil analisis data postes kelas eksperimen diperoleh skor tertinggi 37 dan skor terendah 18. Sedangkan pada kelas kontrol diperoleh skor tertinggi 36 dan skor terendah 10 .

\section{Uji Normalitas}

Pengujian normalitas untuk data pretes, postes, dan gain kemampuan komunikasi matematis untuk kelas eksperimen atau kelas kontrol digunakan rumus Chi-Kuadrat $\left(\chi^{2}\right)$. Uji normalitas dilakukan untuk mengetahui apakah sebaran data berasumsi normal atau tidak. 
Tabel 2. Uji Normalitas Data Pretes, Postes, dan Gain

\begin{tabular}{|c|c|c|c|c|}
\hline Jenis Data & Uji Statistik $\left(\chi^{2}\right)$ & Eksperimen & Kontrol & Kesimpulan \\
\hline \multirow{3}{*}{ Pretes } & $\chi_{\text {hitung }}^{2}$ & 6,29 & 3,40 & \multirow{3}{*}{ Data Normal } \\
\hline & $\mathrm{dk}$ & 4 & 4 & \\
\hline & $\chi_{\text {tabel }}^{2}$ & 9,488 & 9,488 & \\
\hline \multirow{3}{*}{ Postes } & $\chi_{\text {hitung }}^{2}$ & 4,82 & 2,25 & \multirow{3}{*}{ Data Normal } \\
\hline & $\mathrm{dk}$ & 4 & 4 & \\
\hline & $\chi_{\text {tabel }}^{2}$ & 9,488 & 9,488 & \\
\hline \multirow{3}{*}{ Gain } & $\chi_{\text {hitung }}^{2}$ & 4,18 & 5,15 & \multirow{3}{*}{ Data Normal } \\
\hline & $\mathrm{dk}$ & 5 & 5 & \\
\hline & $\chi_{\text {tabel }}^{2}$ & 11,070 & 11,070 & \\
\hline
\end{tabular}

Berdasarkan tabel di atas, untuk $\alpha=0,05$ dengan kriteria $\chi_{\text {hitung }}^{2}<\chi_{\text {tabel }}^{2}$ diasumsikan data berasal dari populasi berdistribusi normal.Jika terjadi sebaliknya maka asumsi data tidak berdistribusi normal.Sesuai dengan kriteria tersebut, dapat disimpulkan bahwa data pretes, posttes, dan gain kemampuan komunikasi matematis kelas eksperimen dan kelas kontrol berdistribusi normal.

\section{Uji Homogenitas}

Setelah uji normalitas, uji prasyarat berikutnya yaitu uji homogenitas. Uji homogenitas digunakan untuk menganalisis suatu data, terkait apakah data tersebut berasal dari populasi yang variansinya sama (homogen) atau tidak. Data dalam penelitian ini yang di uji homogenitasnya meliputi data pretes, data postes, dan data gain kemampuan komunikasi matematis. Uji yang digunakan yaitu uji-F dengan membandingkan varians terbesar dan varians terkecil.

Tabel 3. Uji Homogenitas Data Pretes, Postes, dan Gain

\begin{tabular}{cccc}
\hline Keterangan & Pretes & Postes & Gain \\
\hline $\mathrm{F}_{\text {hitung }}$ & 1,04 & 1,05 & 3,75 \\
\hline dk pembilang & 30 & 30 & 31 \\
\hline dk penyebut & 31 & 31 & 30 \\
\hline $\mathrm{F}_{\text {tabel }}$ & 1,83 & 1,83 & 1,83 \\
\hline Kesimpulan & Homogen & Homogen & Tidak Homogen \\
\hline
\end{tabular}

Untuk $\alpha=0,05$ dengan kriteria jika $\mathrm{F}_{\text {hitung }}<\mathrm{F}_{\text {tabel }}$ maka data homogen.Jika terjadi sebaliknya maka data tidak homogen. Berdasarkan tabel diatas, data pretes dan postes diperoleh $\mathrm{F}_{\text {hitung }}$ lebih kecil dari $\mathrm{F}_{\text {tabel }}$ yaitu 1,04< 1,83 untuk data pretes, 1,05< 1,83 untuk data postes. Maka dapat disimpulkan bahwa data pretes dan postes kelas eksperimen dan kelas kontrol berasal dari variansi yang sama (homogen). Berbeda dengan data gain kemampuan komunikasi matematis diperoleh $\mathrm{F}_{\text {hitung }}$ lebih besar dari $\mathrm{F}_{\text {tabel }}$. Maka dapat disimpulkan bahwa data gain kemampuan komunikasi matematis tidak homogen. 


\section{Uji Perbedaan Dua Rata-Rata}

Uji prasyarat yang sudah dilakukan sebelumnya, diperoleh data pretes dan posteskemampuan komunikasi matematis kelas eksperimen dan kelas kontrol berdistribusi normal dan homogen, sedangkan untuk data gain kemampuan komunikasi matematis kedua kelas diperoleh bahwa data berdistribusi normal tetapi tidak homogen. Analisis dapat dilanjutkan dengan uji perbedaan dua ratarata untuk menguji hipotesis yang sudah dibuat. Uji perbedaan dua rata-rata yang digunakan untuk data pretes dan postes yaitu uji- $t$ dengan taraf signifikansi $\alpha=0,05 \mathrm{dan} \mathrm{dk}=61$. Sementara untuk data gain kemampuan komunikasi matematis menggunakan uji-t' dengan taraf signifikansi $\alpha=0,05$.

Data pretes dianalisis untuk mengetahui apakah terdapat perbedaan kemampuan komunikasi matematis siswa antara kelas eksperimen dan kelas kontrol sebelum diberikan pembelajaran.Uji perbedaan dua rata-rata yang digunakan yaitu uji- $t$ dua pihak. Pada tabel $t$ menunjukkan bahwa $t_{\text {tabel }}$ dengan dk $=61$ untuk uji dua pihak adalah 1,999, sedangkan nilai $t_{\text {hitung }}$ didapat sebesar 0,354 . Karena $-t_{\text {tabel }} \leq t_{\text {hitung }} \leq t_{\text {tabel }}$ atau $-1,999 \leq 0,354 \leq 1,999$ maka $\mathrm{H}_{0}$ diterima, sehinggga dapat disimpulkan bahwa tidak terdapat perbedaan kemampuan komunikasi matematis awal siswa antara kelas eksperimen dan kelas kontrol.

Uji perbedaan dua rata-rata untuk data posteskemampuan komunikasi matematis menggunakan uji-t. Uji- $t$ yang digunakan yaitu uji satu pihak yaitu pihak kanan.Uji ini merupakan pembuktian dari hipotesis 1 yaitu untuk mengetahui apakah pencapaian akhir kemampuan komunikasi matematis siswa kelas eksperimen lebih tinggi daripada kelas kontrol. Pada tabel $t$ menunjukkan bahwa $t_{\text {tabel }}$ dengan $\mathrm{dk}=61$ untuk uji satu pihak adalah 1,671, sedangkan nilai $t_{\text {hitung }}$ adalah 1,84. Karena $t_{\text {hitung }} \geq t_{\text {tabel }}$ atau 1,84> 1,671 maka $\mathrm{H}_{0}$ ditolak dan $\mathrm{H}_{1}$ diterima, sehinggga dapat disimpulkan bahwa pencapaian akhir kemampuan komunikasi matematis siswa kelas eksperimen lebih tinggi daripada kelas kontrol. Dapat ditarik kesimpulan bahwa Pencapaian akhir kemampuan komunikasi matematis siswa yang mendapatkan model pembelajaran the power of two lebih tinggi daripada siswa yang mendapatkan model pembelajaran ekspositori.

Uji prasyarat sebelumnya menyatakan bahwa data gainkemampuan komunikasi matematis kedua kelas berdistribusi normal tetapi tidak homogen. Uji perbedaan dua rata-rata yang digunakan uji-t' satu pihak yaitu pihak kanan.Uji ini merupakan pembuktian dari hipotesis 2 yaitu untuk mengetahui apakah peningkatan kemampuan komunikasi matematis siswa kelas eksperimen lebih baik daripada kelas kontrol. Didapat nilai $t_{\text {hitung }}$ sebesar 4,375.Berdasarkan hasil perhitungan nilai $t^{\prime} \geq \frac{w_{1} t_{1}+w_{2} t_{2}}{w_{1}+w_{2}}$ atau 4,375>1,686. Karena $t^{\prime} \geq \frac{w_{1} t_{1}+w_{2} t_{2}}{w_{1}+w_{2}}$ sehingga $\mathrm{H}_{0}$ ditolak dan $\mathrm{H}_{1}$ diterima yaitu peningkatan kemampuan komunikasi matematis siswa kelas eksperimen lebih tinggi daripada siswa kelas kontrol. Dapat ditarik kesimpulan Peningkatan kemampuan komunikasi matematis siswa yang mendapatkan model pembelajaran the power of two, lebih tinggi siswa yang mendapatkan daripada siswa yang mendapatkan model pembelajaran ekspositori. 


\section{SIMPULAN DAN SARAN}

Berdasarkan hasil penelitian menunjukkan bahwa pertama, pencapaian akhir kemampuan komunikasi matematis siswa yang mendapatkan model pembelajaran the power of two lebih tinggi daripada siswa yang mendapatkan model pembelajaran ekspositori. Kedua, peningkatan kemampuan komunikasi matematis siswa yang mendapatkan model pembelajaran the power of two, lebih tinggi siswa yang mendapatkan daripada siswa yang mendapatkan model pembelajaran ekspositori. Dengan demikian model pembelajaran kooperatif tipe the power of two berpengaruh terhadap kemampuan komunikasi matematis.

Dari kesimpulan yang diperoleh, peneliti memberikan saran untuk penelitian berikutnya agar menerapkan pembelajaran kooperatif tipe the power of two untuk meningkatkan kemampuan kognitif maupun afektif lain berdasarkan tinjauan dan materi yang berbeda agar dapat menambah pengetahuan untuk peneliti sendiri maupun untuk lingkungan. Selain itu, untuk para guru agar dapat memaksimalkan potensi siswanya dengan memberikan model pembelajaran kooperatif tipe the power of two yang dapat mengembangkan kemampuan komunikasi matematis di lingkungannya.

\section{DAFTAR RUJUKAN}

Anisah. (2013). Penerapan Pembelajaran Kooperatif Tipe Two Stay Two Stray (TS-TS) untuk Meningkatkan Kemampuan Matematis Siswa Kelas VII D di SMP Negeri 2 Godean. Jurnal tidak diterbitkan. Yogyakarta: Universitas Negeri Yogyakarta.

Asquith, P., Stephens, A. C., and Knuth, E. J. (2007). "Middle School Mathematics Teachers' Knowlegde of Students' Understanding of Core Algebraic Concepts: Equal Sign and Variable."Journal ofMathematical Thinking and Learning, 9, (3), 249-272. Madison: University of WisconsinMadison.

Badan Standar Nasional Pendidikan. (2006). "Standar Isi untuk Satuan Pendidikan Dasar dan Menengah: Standar Kompetensi dan Kompetensi Dasar SMP/MTs."Onlinehttp://bsnpindonesia.org/id/?page_id=103/.(Diakses Sabtu, 24 September 2019 Pukul 10.31 WIB).

Baroody. A. J. (1993). Problem Solving, Reasoning, and Communicating. New York: Macmillan Publishing.

Kadir. (2010). Penerapan Pembelajaran Kontekstual Berbasis Potensi Pesisir Sebagai Upaya Peningkatan Kemampuan Pemecahan Masalah, Komunikasi, dan Keterampilan Sosial Siswa SMP.Disertasi tidak diterbitkan. Bandung: Universitas Pendidikan Indonesia.

National Council of Teacher Mathematics (NCTM). (1989). Curriculum and Evaluation Standards for School Mathematics. Reston, VA: NCTM.

National Council of Teacher Mathematics.(2000). Principles and Standards for School Mathematics. Reston, VA: NCTM.

Pujiastuti, H. (2014). Pembelajaran Inquiry Co-Operation Model untuk Meningkatkan Kemampuan Pemecahan Masalah, Komunikasi, dan Self- 
Esteem Matematis Siswa SMP.Disertasi tidak diterbitkan. Bandung: Universitas Pendidikan Indonesia.

Safrilda. (2012). Peningkatan Kemampuan Komunikasi dan Disposisi Matematis Siswa melalui Pendekatan Matematika Realistik.Tesis tidak diterbitkan.Medan: Universitas Negeri Medan.

Sanaky, Hujair AH. (2006). Metode dan Strategi Pembelajaran Berorientasi pada Pemberdayaan Peserta Didik, (Online),(http://sanaky.com, diakses Jum'at, 28 November 2019).

Silberman, Melvin L. (2007). Active Learning Strategi Pembelajaran Aktif. Yogyakarta: Pustaka Insan Madani.

Sumarmo, U. (2006). Pembelajaran Keterampilan Membaca Matematika pada Siswa Sekolah Menengah.Jurnal tidak diterbitkan. Bandung: Universitas Pendidikan Indonesia.

Sumarmo. (2010). Berfikir dan Disposisi Matematik:Apa, Mengapa, dan Bagaimana dikembangkan pada Peserta Didik. Jurnal tidak diterbitkan.. Bandung: Universitas Pendidikan Indonesia.

Suprijono, Agus. (2013). Cooperative Learning Teori dan Aplikasi Paikem. Yogyakarta: Pustaka Pelajar.

Yaniawati, R. P. (2010). E-Learning Alternatif Pembelajaran Kontemporer.Bandung: Arfino Raya.

Zainab. (2011). Komunikasi Matematis dalam Pembelajaran Matematika.Jurnal.Tidak diterbitkan.

Zaini, H., Munthe, B \& Aryani, S. A. (2008). Strategi Pembelajaran Aktif. Yogyakarta: Pustaka Insan Madani. 